\title{
Pengaruh Ukuran Perusahaan, Profitabilitasdan Financial Leverage Terhadap Praktik Perataan Laba Pada Perusahaan Manufaktur
}

\author{
Ni Putu Nanda Ayunika ${ }^{1}$ \\ I Ketut Yadnyana ${ }^{2}$
}

${ }^{1}$ Fakultas Ekonomi dan Bisnis Universitas Udayana (Unud), Bali, Indonesia email:nandaayunika5@gmail.com/ Telp :085738537078

${ }^{2}$ Fakultas Ekonomi dan Bisnis Universitas Udayana (Unud), Bali, Indonesia

\begin{abstract}
ABSTRAK
Tujuan dari penelitian ini yaitu untuk memperoleh bukti empiris pengaruh ukuran perusahaan, profitabilitas, dan financial leverage terhadap praktik perataan laba (income smoothing). Penelitian ini dilakukan pada perusahaan manufaktur yang terdaftar di Bursa Efek Indonesia periode 2015-2017. Populasi dalam penelitian ini sebanyak 153 perusahaan. Metode penentuan sampel dengan purposive sampling. Jumlah sampel yang diperoleh sebanyak 46 sampel dengan pengamatan selama 3 tahun sehingga terdapat 138 amatan. Praktik perataan laba dihitung menggunakan Indeks Eckel dan teknik analisis yang digunakan analisis regresi logistik dengan menggunakan bantuan program komputer SPSS (Statistical Package For Social Saint).Hasil analisis pada penelitian ini menunjukkan bahwa model regresi ukuran perusahaan, profitabilitas, dan financial leverage berpengaruh positif signifikan terhadap praktik perataan laba (income smoothing) pada perusahaan manufaktur yang terdaftar di Bursa Efek Indonesia periode 2015-2017.
\end{abstract}

Kata kunci:praktik perataan laba, ukuran perusahaan, profitabilitas, financial leverage

\begin{abstract}
The purpose of this study is to obtain empirical evidence of the effect of company size, profitability, and financial leverage on income smoothing. This research was conducted at manufacturing companies listed on the Indonesia Stock Exchange for the period 20152017. The population in this study were 153 companies. The method of determining the sample with purposive sampling. The number of samples obtained was 46 samples with observations for 3 years so there were 138 observations. The practice of income smoothing was calculated using the Eckel Index and the analysis technique used was logistic regression analysis using the help of the SPSS computer program (Statistical Package For Social Saint). The results of the analysis in this study indicate that the regression model of company size, profitability, and financial leverage has a significant positive effect on income smoothing in manufacturing companies listed on the Indonesia Stock Exchange for the period 2015-2017.
\end{abstract}

Keywords: income smoothing practices, company size, profitability, financial leverage 
Ni Putu Nanda Yunika dan I Ketut Yadnyana. Pengaruh...

\section{PENDAHULUAN}

Perkembangan laba yang dihasilkan perusahaan sangat mempengaruhi masa depan perusahaan, hal ini tercermin dari minat investor terhadap perusahaan dengan tingkat saham yang stabil daripada perusahaan dengan meningkatkan laba yang tinggi. Bagi para investor, perusahaan dengan tingkat laba yang stabil lebih memberikan jaminan keamanan dalam berinvestasi dan mempunyai masa depan perusahaan yang baik serta kelangsungan perusahaan dalam jangka panjang. Terpusatnya perhatian investor terhadap informasi laba tanpa memperhatikan bagaimana prosedur dalam memperoleh data dan dalam berinvestasi cenderung hanya fokus pada hasil akhir laporan laba yang disajikan tanpa melihat atau mencari tahu tentang perolehan laba tersebut menjadikan peluang bagi manajer untuk melakukan strategi yang akan meningkatkan laba perusahaaan (Beattie et $a l, 1994)$.

Dengan demikian adanya dorongan bagi perusahaan yang berusaha mencapai laba yang stabil untuk memenuhi ekspektasi investor agar dinilai baik, sehingga akan berdampak pada kompensasi yang diterimanya. Dengan demikian, perusahaan memiliki insentif untuk melakukan tindakan praktik perataan laba agar mencapai tujuan laba tertentu.Menurut Surya dan Ltrini(2016),praktikperataan laba adalah salah satu pola tindakan manajemen laba yang dilakukan oleh pihak manajer untuk mengurangi fluktuasi laba yang dilakukan sehingga laba terlihat stabil dari periode ke periode. Menurut Nejad, dkk (2013), definisi sederhana dari praktik perataan laba adalah suatu tindakan yang sengaja dilakukan oleh manajer dengan menggunakan kebijakan akuntansi 
untuk mengurangi fluktuasi laba. Praktik perataan laba dilakukan untuk menghasilkan informasi laba yang tidak mencerminkan kondisi perusahaan yang sesungguhnya. Kondisi ini terjadi adanya kesenjangan informasi antara pemilik dengan manajer perusahaan dimana pihak yang paling mengetahui kondisi perusahaan adalah manajer perusahaan oleh karenanya masalah dalam perataan laba ini tidak terlepas dari adanya asymmetric information.

Menurut Barnea, dkk (1975) para manajemen melakukan praktikperataan laba untuk mengurangi fluktuasi laba yang dilaporkan dan meningkatkan kemampuan investor untuk memprediksi aliran kas dimasa depan. Menurut Michelson et al (1995) menyimpulkan perusahaan yang melakukan perataan laba memiliki return tahunan rata-rata dan resiko yang lebih rendah secara signifikan dari perusahaan yang tidak melakukan perataan laba. Mengenai dampak dari adanya tindakan praktik perataan laba menjadikan informasi yang menyesatkan para investor dalam melakukan tindakan pengambilan keputusan yang berakibat kesalahan yang membuat kerugian.

Menurut Utomo dan Baldric (2008) alasan mengapa peristiwa perataan laba perlu diteliti adalah timbulnya kerugian bagi pihak-pihak yang berkepentingan terhadap perusahaan karena adanya praktik perataan laba. Adanya perataan laba mengakibatkan penggungkapan informasi mengenai laba yang keliru. Hal ini mengakibatkan terjadinya kesalahan pengambilan keputusan oleh pihak eksternal.

Praktik perataan laba berhubungan dengan manajemen laba yang megandung unsur teori sinyal (signalling theory) dan teori akuntansi positif 
Ni Putu Nanda Yunika dan I Ketut Yadnyana. Pengaruh...

(positive accounting theory).Brigham dan Hauston (2006:31) menyatakan bahwa isyarat atau sinyal adalah suatu tindakan yang diambil perusahaan untuk memberikan petunjuk bagi investor tentang bagaimana manajemen memandang prospek perusahaan. Saat informasi diumumkan hal yang pertama dilakukan oleh para investor adalah dengan cara menganalisis apakah informasi tersebut merupakan sinyal baik (good news) atau sinyal buruk (bad news). Maka dari itu dari informasi sinyal-sinyal yang beredar dapat mempengaruhi tindakan yang diambil oleh para investor. Teori akuntansi positif adalah teori yang memprediksi tindakan pemilihan kebijakan akuntansi oleh manajer dan bagaimana manajer akan merespon kebijakan akuntansi baru yang diusulkan (Scott, 2006). Tujuan dari praktik perataan laba untuk memodifikasi laba akuntansi dalam memberi tanggapan positif terhadap tanggapan kinerja mereka disamping juga untuk memperoleh tanggapan positif dari pasar atas informasi yang disajikannya.

Dewi dan Sujana (2014) menyatakan salah satu objek perataan laba adalah laba akutansi. Laba mempunyai keterkaitan dengan ukuran perusahaan. Ukuran perusahaan merupakan suatu skala yang diklasifikasikan menurut berbagai cara, antara lain total aset, log size, nilai pasar saham, dan lain-lain. Pada dasarnya ukuran perusahaan terbagi dalam kategori yaitu besar, kecil dan menengah. Perkembangan ukuran suatu perusahaan sangat mempengaruhi perhatian dan ketertarikan para analis, investor maupun pemerintah dalam menilai kelangsungan perusahaan kedepannya.Perusahaan besar akan menghindari fluktuasi laba yang drastis dengan melakukan tindakan perataan laba, karena perusahaan nantinya 
akan dibebani pajak yang besar dan meminimalisir resiko yang kemungkinan akan terjadi.

Menurut Budiasih (2009) ukuran perusahaan dapat dilihat dari total aktiva perusahaan di mana, semakin besar jumlah aktiva pada perusahaan semakin baik kinerja perusahaan dalam menghasilkan dana untuk membayar hutang perusahaan. Namun perusahaan besar diperkirakan lebih menghindari fluktuasi laba yang drastis. Karena jika terjadi penurunan laba akibat tidak langsung dari penurunan aktiva dapat menyebabkan dampak buruk bagi perusahaan. Oleh karena itu perusahaan besar diduga lebih melakukan praktik perataan laba.

Setiap perusahaan mempunyai kemampuan untuk memperoleh laba yang disebut dengan profitabilitas perusahaan. Bagi investor menganalisis profabilitas sebuah perusahaan jangka panjang akan sangat penting bagi pemegang saham. Pemegang saham akan melihat keuntungan yang diterima dalam bentuk dividen (Prayudi dan Daud, 2013). Profitabilitas digunakan untuk mengevaluasi kinerja manajemen dalam menilai efektif atau tidaknya dalam bekerja. Jika suatu perusahaan mempunyai profitabilitas tinggi maka manajemen cenderung akan melakukan perataan laba karena manajemen mengetahui kemampuan perusahaan untuk mendapatkan laba dimasa depan, sedangkan perusahaan yang kinerjanya lebih rendah tentu akan mencoba untuk mengangkat kinerjanya dengan melakukan manajemen laba tetapi mereka tentu lebih sulit untuk menutupinya ditahun berikutnya sehingga tidak terjadi perataan, tetapi lebih kepada income increasing selama beberapa periode. 
Ni Putu Nanda Yunika dan I Ketut Yadnyana. Pengaruh...

Financial leverage menunjukkan sejauh mana aset perusahaan telah dibiayai oleh penggunaan hutang. Semakin besar utang perusahaan maka semakin besar pula risiko yang dihadapi investor sehingga investor akan meminta tingkat keuntungan yang semakin tinggi dalam perusahaan. Financial leverage merupakan hal penting dalam perusahaan dengan berdasarkan penggunaan sumber keuangan yang memiliki beban tetap dengan tujuan untuk menghasilkan laba yang lebih besar. Serta jika perusahaan memiliki hutang yang relatif besar tentunya akan mempunyai resiko semakin meningkat. Maka akan dapat memicu perusahaan untuk melakukan tindakan perataan laba untuk menstabilkan posisi keuangan perusahaan.

Berikut hasil dan pembahasan penelitian rekapitulasi perhitungan terjadinya praktik perataan laba (income smoothing) dengan menggunakan rumus indeks eckelCV $\Delta \mathrm{I}$ dan $\mathrm{CV} \Delta$ Spada perusahaan manufaktur di Bursa Efek Indonesia tahun 2015-2017:

Tabel 1.1

Rekapitulasi Perhitungan Income Smoothing pada Perusahaan Manufaktur di Bursa Efek Indonesia Tahun 2015-2017

\begin{tabular}{|c|c|c|c|c|}
\hline Kategori & $\begin{array}{c}\text { Tidak Perataan } \\
\text { Laba }\end{array}$ & $\begin{array}{c}\text { Perataan } \\
\text { Laba }\end{array}$ & $\begin{array}{c}\text { Total } \\
\text { Sampel }\end{array}$ & $\begin{array}{l}\text { Indikasi Tindakan } \\
\text { Perataan laba }\end{array}$ \\
\hline \multirow{3}{*}{$\begin{array}{c}\text { Perusahaan } \\
\text { Manufaktur tahun } \\
\text { 2015-2017 }\end{array}$} & 14 & 8 & 22 & $63,6 \%$ \\
\hline & 11 & 13 & 24 & $54,2 \%$ \\
\hline & & & & \\
\hline \multicolumn{3}{|c|}{ Total } & 46 & $58,7 \%$ \\
\hline
\end{tabular}

Sumber : Data diolah, 2018

Bedasarkan tabel di atas dapat dilihat bahwa perusahaan manufaktur pada tahun 2015-2017 yang kemungkinan cenderung tidak melakukan praktik perataan laba (income smoothing) terdapat 22 perusahaan manufaktur artinya terdapat 14 
perusahaan manufaktur yang tidak melakukan praktik perataan laba sedangkan 8 perusahaan manufaktur melakukan praktik perataan laba dengan tindakan indikasi sebesar $63,6 \%$. Perusahaan manufaktur yang melakukan praktik perataan laba (income smoothing) terdapat 24 perusahaan manufaktur artinya 13 perusahaan manufaktur cenderung akan melakukan praktik perataan laba sedangkan 11 perusahaan tidak melakukan praktik perataan laba dengan tindakan indikasi pada perusahaan manufaktur tersebut sebesar 54,2 \%. Hal ini membuktikan bahwa cenderung perusahaan manufaktur untuk melakukan praktik perataan laba mengalami kenaikan itu menandakan manajemen semakin berusaha untuk memperlihatkan kinerja perusahaan yang baik sehingga dapat menarik para investor.

Praktik perataan laba terjadi di perusahaan manufaktur dipilih sebagai sampel karena perusahaan manufaktur merupakan perusahaan yang menjual produknya yang dimulai dari proses produksi yang tidak terputus mulai dari pembelian bahan baku, pengolahan bahan hingga menjadi produk yang siap dijual dan juga perusahaan manufaktur memiliki sistem pencatatan akuntansi yang kompleks. Penelitian yang terkait dengan perataan laba sudah banyak di lakukan namun masih menunjukkan hasil yang berbeda-beda. Budiasih (2009), Prabayanti dan Yasa (2011) membuktian bahwa ukuran perusahaan, profitabilitas berpengaruh positif terhadap praktik perataan laba sedangkan financial leverage berpengaruh negatif terhadap praktik perataan laba.Penelitian Prasetya dan Raharjo (2013) menunjukkan hasil bahwa financial leverage berpengaruh positif terhadap praktik perataan laba, sedangkan ukuran perusahaan, profitabilitas tidak 
Ni Putu Nanda Yunika dan I Ketut Yadnyana. Pengaruh...

berpengaruh signifikan terhadap praktik perataan laba. Dalam penelitian yang dilakukan oleh Dewi dan Sujana (2014) membuktikan bahwa profitabilitas dan ukuran perusahaan berpengaruh signifikan terhadap praktik perataan laba.

Ukuran perusahaan diduga menjadi salah satu faktor yang mendorong manajemen melakukan praktik perataan laba. Hal ini disebabkan karena segala informasi yang dikeluarkan oleh perusahaan akan mendapat perhatian dari para invetor. Dapat dikaitkannya dengan teori sinyal yang menjelaskan dalam memberikan informasi laporan keuangan, perusahaan mempunyai dorongan asimetri informasi antara pihak eksternal dengan perusahaan terhadap keputusan investasi dari investor dipasar modal.

Menurut Keiso dan Weygand (2010:260) dalam Peranasari dan Dharmadiksa (2014) semakin besar ukuran perusahaan maka semakin banyak mendapatkan perhatian baik dari para invetor, para analis, pemerintah. Bestivano (2013) menemukan bukti bahwa perusahaan yang lebih besar memiliki dorongan yang lebih besar pula untuk melakukan praktik perataan laba dibandingkan dengan perusahaan yang lebih kecil.

Perusahaan besar diperkirakan akan menghindari fluktuasi laba yang terlalu drastis, sebab kenaikan laba yang drastis akan menyebabkan pertambahan pajak. Sebaliknya penurunan laba yang drastis, akan menyebabkan kesan atau nilai perusahaan menjadi kurang baik.Untuk itu perusahaan yang besar lebih diperhatikan oleh masyarakat sehingga akan lebih berhati-hati dalam melakukan pelaporan keuangan, sehingga berdampak pada perusahaan tersebut melaporkan kondisinya lebih akurat (Abiprayu dan Irene, 2011).Oleh karena itu perusahaan 
besar diperkirakan memiliki kecenderungan yang lebih besar untuk melakukan tindakan praktik perataan laba.Dalam penelitian ini, pengukuran terhadap ukuran perusahaan menggunakan logaritma natural dai kapitalisasi pasar (Apriansyah, 2016).

Bedasarkan penelitian lain yang dilakukan oleh Cendy (2013), Dewi dan Sujana (2014), serta Puspareni (2015) menyimpulkan bahwa ukuran perusahaan berpengaruh positif signifikan terhadap praktik perataan laba. Bedasarkan uraian tersebut maka hipotesisnya yang diajukan dalam penelitian ini yaitu :

$\mathrm{H}_{1}$ : Ukuran perusahaan berpengaruh positif signifikan terhadap praktik perataan laba (income smoothing) pada perusahaan manufaktur di Bursa Efek Indonesia tahun 2015-2017.

Profitabilitas dapat dijadikan patokan oleh investor maupun kreditor dalam menilai sehat tidaknya perusahaan. Profitabilitas diduga mempengaruhi perataan laba, karena profitabilitas secara langsung terkait dengan objek perataan laba. Dalam teori sinyal menggambarkan pentingnya memberikan informasi laporan keuangan dan perusahaan akan menggambil suatu tindakan untuk memberikan petunjuk bagi para investor tentang bagaimana prospek perusahaan kedepannya.

Profitabilitas perusahaan digunakan untuk mengukur kemampuan perusahaan dalam memperoleh laba bersih dan mengetahui efektivitas perusahaan dalam mengelola asset yang disebut dengan ROA (Return On Asset). Semakin tinggi tingkat perubahan ROA semakin tinggi pula fluktuasi kemampuan manajemen dalam menghasilkan laba. Tingkat profitabilitas atau ROA yang tinggi akan memberikan keyakinan bagi investor bahwa perusahaan memiliki kinerja yang baik dan juga dapat mempengaruhi dalam pengambilan keputusan investasi 
Ni Putu Nanda Yunika dan I Ketut Yadnyana. Pengaruh...

kedepannya, sebaliknya jika terjadi tingkat profitabilitas yang rendah menunjukan bahwa kinerja perusahaan mengalami penurunan.Kenaikan dan penurunan inilah yang dihindari manajer terkait penilaian kinerja karena investorlebih menyukai kestabilan pendapatan yang dapat menunjukkan bahwa perusahaan memiliki kinerja yang baik daripada pendapatan yang fluktuatif laba maka dari itu perusahaan akan mendorong para manjemen untuk melakukan praktik perataan laba.

Penelitian mengenai praktik perataan laba menurut Pratiwi dan Handayani (2014) bahwa perusahaan dengan tingkat profitabilias yang rendah mempunyai kecenderungan lebih besar melakukan praktik perataan laba yang menunjukkan bahwa profitabilitas berpengaruh negatif terhadap praktik perataan laba. Penelitian tentang pengaruh profitabilitas terhadap praktik perataan laba tidaksejalan dengan yang dilakukan oleh Dewi dan Sujana (2014), Peranasari dan Dharmadiaksa (2014) hasilnya menyimpulkan profitabilitas berpengaruh positif signifikan terhadap perataan laba. Bedasarkan uraian di tersebut maka dapat dirumuskan hipotesis sebagai berikut:

$\mathrm{H}_{2}$ : Profitabilitas berpengaruh positif signifikan terhadap praktik perataan laba (income smoothing) pada perusahaan manufaktur di Bursa Efek Indonesia tahun 2015-2017.

Konsep financial leverage bermanfaat untuk analisis, perencanaan dan pengendalian keuangan. Financial leverage diukur dengan membandingkan rasio antara total hutang dan total aktiva yang disebut dengan debt to total asset. Dalam teori akuntansi positif (positive accounting theory) menjelaskan angka-angka akuntansi dijadikan sebagai informasi yang menjadi basis keputusan dalam 
penentuan alokasi sumber daya, kompensasi manajemen dan pengawasan perjanjian utang, maka dari itu financial leverage menunjukkan proporsi penggunaan utang untuk membiayai investasi para investor.

Perusahaan yang memiliki tinggat leverage yang tinggi atau semakin besar utang perusahaan maka semakin besar pula risiko yang dihadapi investor sehingga investor akan meminta tingkat keuntungan yang semakin tinggi dan investor akan semakin takut untuk menginvestasikan modalnya ke perusahaan karena risikonya tinggi. Adanya indikasi perusahaan menggunakan praktik perataan laba (income smoothing) untuk menghindari pelanggaran perjanjian hutang dengan melihat kemampuan perusahaan untuk melunasi utangnya dengan aktiva yang dimiliki perusahaan dan semakin cepat pelunasan hutang semakin baik perusahaan.

Hal ini sesuai dengan hasil penelitian Alexandri (2014), Yosika (2012), Weston dan Copeland (1996) dalam Dewi dan Sujana (2014) mengemukakan bahwafinancial leverage bepengaruh positif terhadap praktik perataan laba.Bedasarkan uraian tersebut maka dapat dirumuskan hipotesis sebagai berikut:

$\mathrm{H}_{3}$ : Financial leverage berpengaruh positif signifikan terhadap praktik perataan laba (income smoothing) pada perusahaan manufaktur di Bursa Efek Indonesia tahun 2015-2017.

\section{METODE PENELITIAN}

Penelitian ini dilakukan pada Perusahaan Manufaktur di Bursa Efek Indonesia Tahun 2015-2017 dengan cara mengumpulkan laporan keuangan tahunan (annual report) dan data lain yang dipublikasikan oleh BEI melalui ICMD (Indonesia Capital Market Directory) dan mengakses situs www.idx.co.id serta website perusahaan untuk mendapatkan informasi dan data yang diperlukan.Populasi yang 
Ni Putu Nanda Yunika dan I Ketut Yadnyana. Pengaruh...

dimaksud dalam penelitian ini adalah seluruh perusahaan manufaktur yang terdaftar di Bursa Efek Indonesia (BEI) tahun 2015-2017.Sampel dalam penelitian ini adalah perusahaan manufaktur yang dipilih dengan menggunakan teknikpurposive sampling di Bursa Efek Indonesia periode 2015-2017.

Praktik perataan laba dan bukan praktik perataan laba menggunakan Indeks Eckel. Indeks Eckel merupakan alat pengklasifikasian yang tepat untuk memisahkan perusahaan praktik perataan laba dengan perusahaan yang bukan praktik perataan laba (Eckel, 1981). Apabila $\mathrm{CV} \Delta \mathrm{I}<\mathrm{CV} \Delta \mathrm{S}$, maka perusahaan tergolong melakukan praktik perataan laba yang akan diberi simbol 1 apabila nilai dari Indeks Eckel $<1$ sedangkan $\mathrm{CV} \Delta \mathrm{I} \geq \mathrm{CV} \Delta \mathrm{S}$, maka perusahaan tergolong tidak melakukan praktik perataan laba akan diberi nilai 0 apabila nilai dari Indeks Eckel $\geq 1$.

Tabel 1.

Kriteria Praktik Perataan Laba

\begin{tabular}{cc}
\hline Keterangan & Kriteria \\
\hline CV $\Delta \mathrm{I}<\mathrm{CV} \Delta \mathrm{S}$ & Melakukan praktik perataan laba \\
$\mathrm{CV} \Delta \mathrm{I} \geq \mathrm{CV} \Delta \mathrm{S}$ & Tidak melakukan praktik perataan laba \\
\hline Sumber:
\end{tabular}
Sumber: Eckel, 1981

Adapun untuk menghitung Indeks Eckeldapat menggunakan rumus sebagai berikut:

$\mathrm{CV} \Delta \mathrm{I}$

$$
\text { Indeks Eckel }=\overline{\mathrm{CV} \Delta \mathrm{S}}
$$

Keterangan :

$\mathrm{CV}=$ Koefisien variasi dari variabel, yaitu standar deviasi dibagidengan nilai yang diharapkan.

$\Delta \mathrm{I}=$ Perubahan laba dalam satu periode.

$\Delta \mathrm{S}=$ Perubahan penjualan dalam satu periode.

$\mathrm{CV} \Delta \mathrm{I}$ dan $\mathrm{CV} \Delta \mathrm{S}$ dirumuskan sebagai berikut : 


$$
\mathrm{CV} \Delta \mathrm{I} \text { dan } \mathrm{CV} \Delta \mathrm{S}=\sqrt{\frac{\sum(\Delta \mathrm{x}-\overline{\Delta \mathrm{X}})^{2}}{\mathrm{n}-1}}
$$

Keterangan :

$\Delta \mathrm{x}=$ Perubahan penghasilan bersih/laba (I) / penjualan (S) antara tahun $\mathrm{n}-1$. $\Delta X=$ Rata-rata perubahan penghasilan bersih/ laba atau penjualan antara tahun $\mathrm{n}-1$.

$\mathrm{n}=$ Banyaknya tahun yang diteliti

Penentuan ukuran perusahaan ini didasarkan pada log aktiva atau logaritma natural aktiva agar menghindari terjadinya fluktuasi data yang berlebihan(Ashari, 1994) yang dirumuskan sebagai berikut :

Ukuran perusahaan $=L n$ Total Aktiva

Alat ukur rasio profitabilitas dalam penelitian ini adalah Return On Asset (ROA) (Brigham, 2006:109) yang dirumuskan sebagai berikut :

$$
\mathrm{ROA}=\frac{\text { Laba Bersih Setelah Pajak }}{\text { Total Aset }} \times 100 \%
$$

Dalam penelitian kali ini rasio financial leverage akan diwakili oleh debt to total assets (DAR) (Aji dan Mita, 2010) yang dirumuskan sebagai berikut :

$$
\mathrm{DAR}=\frac{\text { Total Hutang }}{\text { Total Aset }} \times 100 \%
$$

Penelitian ini yang digunakan dalam pengujian hipotesis dengan menggunakan model regresi logistik. Adapun untuk menguji hipotesis secara keseluruhan dalam penelitian ini adalah sebagai berikut :

$$
\frac{\operatorname{Ln}(P L)}{1-P L}=\alpha+\beta_{1} X_{1}+\beta_{2} X_{2}+\beta_{3} X_{3}+\varepsilon
$$


Ni Putu Nanda Yunika dan I Ketut Yadnyana. Pengaruh...

Keterangan:

$\operatorname{Ln}(\mathrm{PL})$

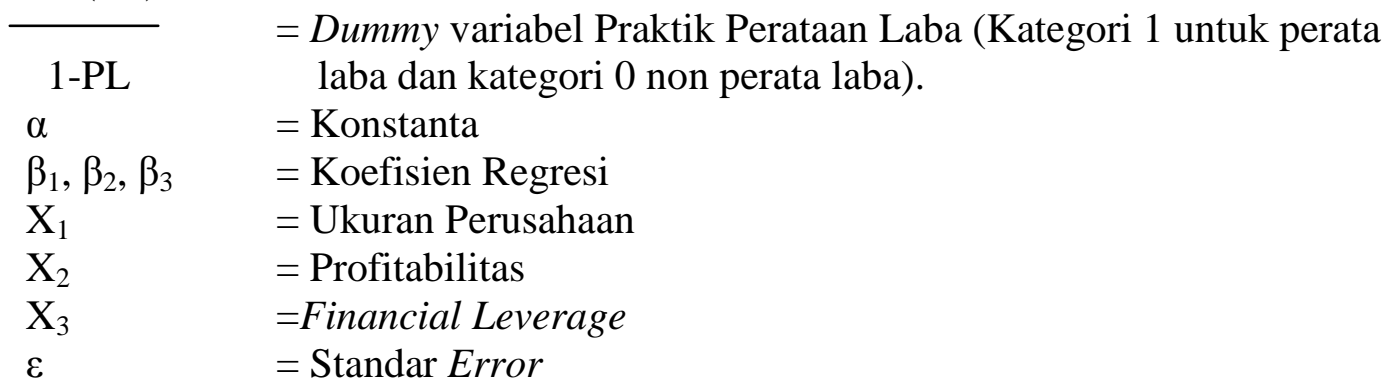

\section{HASIL DAN PEMBAHASAN}

Adapun hasil dari statistic deskrptif dalam penelitian ini tercantum dalam tabel 2 di bawah ini:

Tabel 2.

Hasil Analisis Statistik Deskriptif

\begin{tabular}{lccccc}
\hline & N & Minimum & Maximum & Mean & Std. Deviation \\
\hline Income Smoothing (Y) & 46 &, 00 & 1,00 &, 5217 &, 50505 \\
Ukuran Perusahaan (X1) & 46 & 23,67 & 30,46 & 27,2283 & 1,73311 \\
Profitabilitas (X2) & 46 & 1,14 & 58,61 & 16,1726 & 14,45516 \\
Financial Leverage (X3) & 46 & 10,21 & 76,89 & 39,6552 & 17,70556 \\
Valid N (listwise) & 46 & & & & \\
\hline
\end{tabular}

Sumber: Data diolah, 2018

Bedasarkan Tabel 2 dapat dijelaskan hasilnya bahwa variabel Income Smoothing (Y) adalah perataan laba yang memiliki nilai minimun 0,00 dan nilai maksimum 1,00. Hal ini menunjukkan variabel perataan laba merupakan variabel dummy dimana angka 0 menunjukkan perusahaan tidak melakukan praktik perataan laba sedangkan angka 1 perusahaan melakukan praktik perataan laba. Dengan nilai rata-rata sebesar 0,5217 perusahaan yang menjadi sampel melakukan perataan laba. Untuk standar deviasi sebesar 0,50505. Hal ini menunjukkan 
perbandingan perbedaan yang diteliti dalam melakukan praktik perataan laba (income smoothing).

Variabel Ukuran Perusahaan $\left(\mathrm{X}_{1}\right)$ diperoleh nilai minimum sebesar 23,67 yang dimiliki oleh Japfa Comfeed Indonesia Tbk, sedangkan nilai maksimal sebesar 30,46 yang dimiliki oleh Unilever Indonesia Tbk. Secara keseluruhan variabel ukuran perusahaan memiliki rata-rata sebesar 27,2283 dan standar deviasi 1,73311 .

Variabel Profitabilitas $\left(\mathrm{X}_{2}\right)$ diperoleh nilai minimum sebesar 1,14 yang dimiliki oleh Ricky Putra Globalindo Tbk, sedangkan nilai maksimal sebesar 58,61 yang dimiliki oleh Chareon Pokphand Persada Tbk. Secara keseluruhan variabel profitabilitas memiliki rata-rata sebesar 16,1726 dan standar deviasi 14,45516 .

Variabel Financial Leverage $\left(\mathrm{X}_{3}\right)$ diperoleh nilai minimun sebesar 10,21 yang dimiliki oleh Intan Wijaya International Tbk, sedangkan nilai maksimal sebesar 76,89 yang dimiliki oleh Industri Jamu dan Farmasi Sido Tbk pada tahun 2017. Secara keseluruhan variabel financial leverage memiliki rata-rata sebesar 39,6552 dan standar deviasi variabel ini sebesar 17,70556.

Kelayakan model regresi dinilai menggunakan uji Homser and Lemeshow. Uji Homser and Lemeshow menguji hipotesis nol bahwa data empiris cocok atau sesuai dengan model (tidak ada perbedaan antara model dengan data sehingga model dikatakn fit). Hasil pengujian dapat ditampilkan dalam tabel 3. sebagai berikut: 
Ni Putu Nanda Yunika dan I Ketut Yadnyana. Pengaruh...

Tabel 3.

Hasil Uji Homser and Lemeshow

\begin{tabular}{llllll}
\hline Step & Chi-square & Df & Sig. & \\
\hline 1 & & 4,425 & & 7 & 730 \\
\hline Sumber: Data diolah, 2018 & & &
\end{tabular}

Bedasarkan hasil analisis pada Tabel 3 diperoleh bahwa nilai dari uji Homser and Lemeshow yang diukur dengan nilai Chi Square sebesar 4,425 dengan nilai signifikansi sebesar 0,730 . Hal ini menunjukkan nilai signifikansi 0,730>0,05 sehingga hipotesis nol diterima dan berarti model mampu memprediksi nilai observasinya.

Menilai keseluruhan model (Overall Model Fit)dilakukan dengan cara membandingkan nilai antara -2 Log Likelihood (-2LL) pada awal (Block Number =0) dan dengan nilai -2 Log LikeliHood (-2LL) pada akhir (Block Number $=1)$. Jika terjadi penurunan nilai -2 Log Likelihood (-2LL), maka ini menunjukkan model regresi yang baik atau yang disebut dengan model sesuai dengan data yang dihipotesiskan. Hasil pengujian dapat ditampilkan dalam tabel 4 sebagai berikut:

Tabel 4.

Perbandingan nilai -2LL Awal dengan -2LL Akhir

\begin{tabular}{lc}
\hline -2LL awal (Block Number $=0)$ & 63,683 \\
\hline -2LL akhir $($ Block Number $=1)$ & 60,986 \\
\hline Sumber $:$ Data diolah, 2018 &
\end{tabular}

Bedasarkan hasil analisis pada Tabel 4 diperoleh bahwa nilai -2 Log Likelihood (-2LL) pada awal sebesar 63,683 dan -2 Log Likelihood (-2LL) pada akhir sebesar 60,986 dan bedasarkan hasil tersebut terjadinya penurunan nilai. Penurunan nilai -2 Log Likelihood (-2LL) pada awal dan akhir menunjukkan model regresi yang lebih baik atau dengan kata lain model yang dihipotesiskan fit dengan data. 
Nilai Nagelkerke $R$ Square $\left(\mathrm{R}^{2}\right)$ menunjukkan nilai variabilitas variabel dependen yang dapat dijelaskan oleh variabel independen, sedangkan sisanya dijelaskan oleh variabel-variabel lain diluar model penelitian ini. Hasil pengujian dapat ditampilkan dalam tabel 5 sebagai berikut:

Tabel 5.

Hasil Uji Koefisien Determinasi (Nagelkerke $R$ Square $\left(\mathbf{R}^{2}\right)$ )

\begin{tabular}{lrrr}
\hline Step & $\mathbf{- 2 ~ L o g ~ l i k e l i h o o d}$ & Cox \& Snell R Square & Nagelkerke R Square \\
\hline 1 & $60,989^{\text {a }}$ &, 569 &, 676 \\
\hline
\end{tabular}

Sumber : Data diolah, 2018

Bedasarkan hasil analisis pada Tabel 5 diperoleh bahwa nilai Nagelkerke $R$ Square $\left(\mathrm{R}^{2}\right)$ yaitu 0,676 atau sama dengan 67,6 persen yang berarti variabilitas variabel dependen yang dijelaskan oleh variabel independen yaitu sebesar 67,6 persen, sedangkan sisanya sebesar 32,4 persen dijelaskan dari variabel-variabel lain yang tidak dimasukkan atau diluar model penelitian ini.

Pengujian multikolinearitas dalam regresi logistik dapat dilihat dari matriks korelasi. Model regresi yang baik yaitu regresi dengan tidak adanya gejala korelasi yang kuat diantara variabel bebasnya. Apabila nilai matriks korelasi lebih kecil dari 0,8 artinya tidak terdapat gejala multikolinearitas yang serius antar variabel tersebut sedangkan jika nilai matrik korelasi lebih besar dari 0,8 artinya terjadi gejala multikolinearitas.Hasil pengujian dapat ditampilkan dalam Tabel 6 sebagai berikut: 
Tabel 6.

Matrik Korelasi

\begin{tabular}{llrrrr}
\hline & Constant & $\begin{array}{c}\text { Ukuran } \\
\text { Perusahaan } \\
(\mathbf{X 1})\end{array}$ & $\begin{array}{c}\text { Profitabilitas } \\
(\mathbf{X 2})\end{array}$ & $\begin{array}{c}\text { Financial } \\
\text { Leverage (X3) }\end{array}$ \\
\hline Step 1 & Constant & 1,000 &,- 986 &,- 432 &,- 027 \\
& Ukuran Perusahaan &,- 986 & 1,000 &, 343 &,- 121 \\
& (X1) &,- 432 &, 343 & 1,000 &, 215 \\
& Profitabilitas (X2) &,- 027 &,- 121 &, 215 & 1,000 \\
& Financial Leverage & & & &
\end{tabular}

Bedasarkan hasil analisis pada Tabel 6 diperoleh bahwa pengujian matriks korelasi menunjukkan nilai variabel lebih kecil dari 0,8 sehingga dapat disimpulkan bahwa tidak terdapat gejala multikolinearitas yang serius antar variabel bebas tersebut.

Matrik klasifikasi menunjukkan kemampuan kekuatan prediksi dari model regresi untuk meprediksi kemungkinan terjadinya praktik perataan laba (income smoothing) yang dilakukan pada perusahaan manufaktur di Bursa Efek Indonesia periode 2015-2017. Kekuatan prediksi dari model regresi untuk memprediksi terjadinya variabel terikat dinyatakan dalam persen. Hasil pengujian dapat ditampilkan dalam Tabel 7 sebagai berikut:

Tabel 7.

Matrik Klasifikasi

\begin{tabular}{|c|c|c|c|c|c|}
\hline & \multirow[b]{2}{*}{ Observed } & & \multicolumn{3}{|c|}{$\begin{array}{r}\text { Predicted } \\
\text { Income Smoothing (Y) }\end{array}$} \\
\hline & & & $\begin{array}{c}\text { TidakPerataan } \\
\text { Laba }\end{array}$ & $\begin{array}{l}\text { Perataan } \\
\text { Laba }\end{array}$ & $\begin{array}{l}\text { Percentage } \\
\text { Correct }\end{array}$ \\
\hline \multirow[t]{3}{*}{ Step 1} & Income Smoothing & Tidak Perataan Laba & 14 & 8 & 63,6 \\
\hline & $(\mathrm{Y})$ & Perataan Laba & 11 & 13 & 54,2 \\
\hline & Overall Percentage & & & & 58,7 \\
\hline
\end{tabular}

Bedasarkan hasil analisis pada Tabel 7 diperoleh bahwa pengujian kekuatan memprediksi dari model regresi untuk kemungkinan perusahaan tidak melakukan praktik perataan laba adalah sebesar 63,6 persen. Hal ini menunjukkan bahwa dari 
jumlah sampel 138 dari pengamatan selama 3 tahun dengan mengunakan model regresi tersebut, perusahaan yang tidak melakukan praktik perataan laba 14 dan terdapat 8 total observasi melakukan praktik perataan laba. Kekuatan memprediksi dari model regresi kemungkinan perusahaan yang melakukan praktik perataan laba adalah sebsesar 54,2 persen. Hal ini menunjukkan bahwa dari jumlah sampel 132 dari pengamatan selama 3 tahun dengan mengunakan model regresi tersebut, perusahaan yang melakukan praktik perataan laba 13 dan terdapat 11 total observasi tidak praktik melakukan perataan laba.

Model regresi yang terbentuk dapat dijabarkan sebelumnya bahwa analisis regresi logistik yang digunakan dalam penelitian ini adalah sebagai berikut :

$$
\frac{\operatorname{Ln}(\mathrm{PL})}{1-\mathrm{PL}}=\alpha+\beta_{1} \mathrm{X}_{1}+\beta_{2} \mathrm{X}_{2}+\beta_{3} \mathrm{X}_{3}+\varepsilon
$$

Model analisis regresi logistik ini dibentuk dengan nilai estimasi parameter dalam Variables In The Equation.Hasil pengujian dapat ditampilkan dalam Tabel 8 sebagai berikut :

Tabel 8.

\begin{tabular}{|c|c|c|c|c|c|c|c|}
\hline \multirow[t]{4}{*}{$\begin{array}{l}\text { Step } \\
1^{\mathrm{a}}\end{array}$} & $\begin{array}{l}\text { Ukuran Perusahaan } \\
\text { (X1) }\end{array}$ & ,161 & ,198 & 3,663 & 1 &, 022 & 1,175 \\
\hline & Profitabilitas (X2) & ,036 & ,025 & 5,042 & 1 &, 015 & 1,037 \\
\hline & $\begin{array}{l}\text { FinancialLeverage } \\
\text { (X3) }\end{array}$ & ,012 & ,018 & 3,403 & 1 &, 028 & 1,012 \\
\hline & Constant & $-5,325$ & 5,510 & ,934 & 1 & ,334 & ,005 \\
\hline
\end{tabular}

Variabel Dalam Persamaan

Sumber: Data diolah, 2018

Bedasarkan hasil analisis pada Tabel 8 diperoleh bahwa pengujian model regresi yang terbentuk adalah sebagai berikut : 
Ni Putu Nanda Yunika dan I Ketut Yadnyana. Pengaruh...

$\operatorname{Ln}(\mathrm{PL})$

$$
\frac{1-P L}{1-P L}=2,225+0,161 X_{1}+0,036 X_{2}+0,012 X_{3}+\varepsilon
$$

Hasil penelitian terhadap hipotesis pertama dengan menggunakan regresi logistik menghasilkan bahwa ukuran perusahaan memiliki nilai koefisien positif sebesar 0,161 dengan tingkat signifikan sebesar 0,022 lebih kecil dari alpa 0,05. Dengan memiliki arti bahwa ukuran perusahaan berpengaruh positif signifkan terhadap praktik perataan laba (income smoothing) pada perusahaan manufaktur di Bursa Efek Indonesia periode 2015-2017, dan tingkat signifikansi terhadap praktik perataan laba dapat disimpulkan hasil penelitian ini $\mathrm{H}_{1}$ diterima.

Hal ini mencerminkan ukuran perusahaan diproksikan oleh Log Natural Total Aktiva yang dimana hal tersebut menunjukkan bahwa semakin besar ukuran perusahaan maka semakin banyak mendapatkan perhatian baik atau kesan yang baik untuk mempengaruhi ketertarikan bagi para investor berinvestasi karena adanya segala informasi laporan keuangan atau perkembangan suatu perusahaan untuk menilai kelangsungan perusahaan kedepannya. Maka dari itu perusahaan yang memiliki ukuran perusahaan yang besar memiliki dorongan yang lebih besar untuk melakukan praktik perataan laba(income smoothing).Hasil penelitian ini sejalan dengan penelitianCendy (2013),Dewi dan Sujana (2014), serta Puspareni (2015) menyimpulkan bahwa ukuran perusahaan berpengaruh positif signifikan terhadap praktik perataan laba (income smoothing).

Hasil penelitian terhadap hipotesis kedua dengan menggunakan regresi logistik menghasilkan bahwa profitabilitas memiliki nilai koefisien positif sebesar 0,036dengan tingkat signifikansi sebesar 0,015 lebih kecil dari alpa 0,05. Dengan memiliki arti bahwa profitabilitas berpengaruh positif signifikan terhadap praktik 
perataan laba (income smoothing) pada perusahaan manufaktur di Bursa Efek Indonesia periode 2015-2017, dan tingkat signifikansi terhadap praktik perataan laba dapat disimpulkan hasil penelitian ini $\mathrm{H}_{2}$ diterima.

Hal ini mencerminkan bahwa profitabilitas diproksikan oleh Return On Asset (ROA) yang dimana hal tersebut menunjukkan semakin tinggi tingkat Return On Asset (ROA) yang dimiliki oleh perusahaan maka semakin tinggi pula kecenderungan para manajemen melakukan praktik perataan laba, karena profitabilitas merupakan rasio keuangan yang dapat mengukur kinerja perusahaan dalam menghasilkan laba. Dengan tingkat profitabilitas atau Return On Asset (ROA) yang tinggi akan memberikan keyakinan bagi investor untuk menggambil keputusan berinvestasi. Hasil penelitian ini sejalan dengan penelitian Ashari, dkk (1994), Zurroh (1996) dan Peranasari dan Dharmadiaksa (2014) dan yang menyatakan bahwa profitabilitas yang diukur melalui Return On Asset (ROA) menunjukkan pengaruh positif signifikan terhadap praktik perataan laba (income smoothing).

Hasil penelitian terhadap hipotesis ketiga dengan menggunakan regresi logistik menghasilkan bahwa financial leverage memiliki nilai koefisien positif sebesar 0,012 dengan tingkat signifikansi sebesar 0,028 lebih kecil dari alpa 0,05. Dengan memiliki arti bahwa financial leverageberpengaruh positif signifikan terhadap praktik perataan laba (income smoothing) pada perusahaan manufaktur di Bursa Efek Indonesia periode 2015-2017, dan tingkat signifikansi terhadap praktik perataan laba dapat disimpulkan hasil penelitian ini $\mathrm{H}_{3}$ diterima.

Hal ini mencerminkan bahwa financial leverage diproksikan oleh Debt to Total Assets (DAR).Arah koefisien financial leverage memiliki arti positif karena 
Ni Putu Nanda Yunika dan I Ketut Yadnyana. Pengaruh...

hal tersebut menunjukkan jika perusahaan yang memiliki tinggat leverage yang tinggi atau semakin besar utang perusahaan maka semakin besar pula risiko yang dihadapi investor sehingga investor akan meminta tingkat keuntungan yang semakin tinggi dan investor akan semakin takut untuk menginvestasikan modalnya ke perusahaan karena risikonya tinggi.Hal ini sesuai dengan hasil penelitian Alexandri (2014), Yosika (2012), Weston dan Copeland (1996) dalam Dewi dan Sujana (2014) mengemukakan bahwafinancial leverage berpengaruh positif signifikan terhadap praktik perataan laba (income smoothing).

Bedasarkan hasil penelitian memberikan kesimpulan mengenai informasi pengaruh ukuranperusahaan,profitabilitas danfinancial leverage terhadap praktik perataan laba (income smoothing).Dalam penelitian ini dilakukan pada perusahaan manufaktur di Bursa Efek Indonesia tahun periode 2015-2017. Hasil uji dalam penelitian ini menemukan bahwa variabel independen yaitu ukuran perusahaan berpengaruh positif signifikan terhadap praktik perataan laba (income smoothing). Ukuran perusahaan dapat diproksikan oleh log natural dari total aktiva. Penelitian ini mencerminkan menunjukkan bahwa semakin besar ukuran perusahaan maka semakin banyak mendapatkan perhatian baik atau kesan yang baik untuk mempengaruhi ketertarikan bagi para investor berinvestasi, maka dari itu para manajemen melakukan tindakan praktik perataan laba (income smoothing)

Variabel independen profitabilitas juga berpengaruh positif signifikan terhadap praktik perataan laba (income smoothing). Hal ini mencerminkan bahwa profitabilitas diproksikan oleh Return On Asset (ROA) yang dimana hal tersebut menunjukkan semakin tinggi tingkat Return On Asset (ROA) yang dimiliki oleh 
perusahaan maka semakin tinggi pula kecenderungan para manajemen melakukan praktik perataan laba (income smoothing). Variabel independen financial leverage juga berpengaruh positif signifikan terhadap praktik perataan laba (income smoothing). Hal ini mencerminkan bahwa financial leverage diproksikan oleh Debt to Total Assets (DAR). Jika perusahaan yang memiliki tinggat leverage yang tinggi atau semakin besar utang perusahaan maka semakin besar pula risiko yang dihadapi investor, maka dari itu para investor melakukan praktik perataan laba agar para investor tertarik untuk berinvestasi ke perusahaan.

Penelitian ini sejalan dengan teori sinyal (Signalling Theory)dan teori akuntansi positif (Positive Accounting Theory) dimana penjelasan teori sinyal menjelaskan memberikan informasi seperti keterangan, gambaran keadaan perusahaan, serta informasi laporan keuangan perusahaan akan mempunyai dorongan asimetri informasi antara pihak eksternal (investor) dengan perusahaan untuk mengetahui apakah informasi tersebut merupakan signal baik (good news) atau signal buruk (bad news). Teori akuntansi positif (Positive Accounting Theory) juga menjelaskan bahwa angka-angka akuntansi dijadikan sebagai informasi untuk penentuan keputusan berinvestasi, kompensasi manajemen serta pengawasan perjanjian utang bagi para investor.

Hasil penelitian ini diharapkan mampu memberikan implikasi suatu informasi bagi para investor sebagai bahan pertimbangan untuk mengambil keputusan dalam berinvestasi, memberikan pengetahuan mengenai praktik perataan laba serta indikator-indikator yang mempengaruhinya baik internal maupun eksternal dalam perusahaan dan bagi perusahaan emitem hendaknya 
Ni Putu Nanda Yunika dan I Ketut Yadnyana. Pengaruh...

memperhatikan yang dapat mempengaruhi para manajemen dalam melakukan praktik perataan laba sehingga dapat mengantisipasi terjadinya praktik perataan laba (income smoothing) dalam kinerja kuangan perusahaan agar baik dimata para investor.

\section{SIMPULAN}

Ukuran perusahaan berpengaruh positif signifikan terhadap praktik perataan laba (income smoothing) pada perusahaan manufaktur di Bursa Efek Indonesia 20152017. Hal ini bermakna bahwa semakin besar ukuran perusahaan maka semakin banyak mendapatkan perhatian baik atau kesan yang baik untuk mempengaruhi ketertarikan bagi para investor berinvestasi, maka dari itu para manajemen melakukan tindakan praktik perataan laba (income smoothing).

Profitabilitas berpengaruh positif signifikan terhadap praktik perataan laba (income smoothing) pada perusahaan manufaktur di Bursa Efek Indonesia 20152017. Hal ini bermakna bahwa semakin tinggi tingkat Return On Asset (ROA) yang dimiliki oleh perusahaan maka semakin tinggi pula kecenderungan para manajemen melakukan praktik perataan laba (income smoothing).

Financial Leverage berpengaruh positif signifikan terhadap praktik perataan laba(income smoothing) pada perusahaan manufaktur di Bursa Efek Indonesia 2015-2017. Hal ini bermakna bahwa memiliki tinggat leverage yang tinggi atau semakin besar utang perusahaan maka semakin besar pula risiko yang dihadapi investor, maka dari itu para investor melakukan praktik perataan laba agar para investor tertarik untuk berinvestasi ke perusahaan. 
Bagi peneliti selanjutnya diharapkan untuk menambah variabel bebas untuk menambah prediksi dalam pengaruh praktik perataan laba dan penelitian selanjutnya mengamati adanya praktik perataan laba dalam periode waktu yang berbeda dengan jangka waktu penelitian yang lebih lama dari penelitian ini dan memperbanyak jumlah sampel penelitian.

Penelitian ini hanya dilakukan pada perusahaan manufaktur selama 3 tahun periode, akan menjadi lebih baik apabila pada penelitian selanjutnya menggunakan seluruh perusahaan di Bursa Efek Indonesia (BEI), maka akan ada pertimbangan kriteria sampel yang sesuai dalam menggunakan sektor lainnya.

Bagi investor disarankan untuk lebih teliti dan lebih berhati-hati untuk berinvestasi, dalam mendapatkan informasi perusahaan seperti laporan keuangan perusahaan agar terhindar dari praktik perataan laba yang dilakukan oleh para manajemen untuk mendapat keuntungan perusahaannya.

\section{REFERENSI}

Abiprayu, K.B dan Irene Rini Demi Pangestuti, 2011. Pengaruh Profitabilitas, Ukuran Perusahaan, Financial Leverage, Dividend Payout Ratio Terhadap Perataan Laba (Studi Kasus Pada Perusahaan Manufaktur yang Terdaftar di Bursa Efek Indonesia Tahun 2006-2009). Universitas Diponegoro.

Aji, Dhamar Yudho dan Farah Mita (2010) "Pengaruh Profitabilitas, Risiko Keuangan, Nilai Perusahaan, dan Struktur Kepemilikan terhadap Praktik Perataan Laba: Studi Empiris Perusahaan Manufaktur yang Terdaftar di BEI” Jurnal Akuntansi Keuangan dan Manajemen, 1-30. Purwokerto.

Alexandri, Moh.Benny. 2014. Income Smoothing: Impact Factor, Evidence in Indonesia. International Journal of small bussnies and entrepreneurship research. Vol 3(1), pp.21-27.

Aprianyah, Fajar. 2016. Pengaruh Ukuran Perusahaan, Leverage dan Rentabilitas Terhadap Equity Risk Premium pada Perusahaan Manufaktur yang Terhadap di Bursa Efek Indonesia. Skripsi. Universitas Lampung. 
Ni Putu Nanda Yunika dan I Ketut Yadnyana. Pengaruh...

Ashari, N. Koh H.C., Tan S.L., dan Wong, W.H. 1994. Factor Affecting Income Smoothing Among Listed Companies in Singapore. Journal of Accounting and Bussiness Recerch, Auntum, pp.291-304.

Barnea, A., J. Ronen dan S. Sadan, " The Implementation of Accounting Objectives An Application to Extraordinary Items", The Accounting Review, January 1975.

Beattie, V., S. Brown, D. Ewers, B. John, S.Manson, D. Thomas and M, Turner (1994).Extraordinary Items and Income Smooting: A Positiv Accounting Approach. Journal of Business finance and Accounting, Vol.21, N0.6.(September), pp. 791-811.

Bestivano, Wildham, 2013. "Pengaruh Ukuran Perusahaan, Umur Perusahaan, Profitabilitas, dan Leverage Terhadap Perataan Laba Pada Perusahaan yang terdaftar di BEI (Studi Empiris pada Perusahaan Perbankan di BEI)”. Skripsi. Universitas Negeri Padang”.

Brigham, Eugene F., Joel F. Houston. 2006. Fundamentals of Financial Management. Jakarta: Salemba Empat.

Budiasih, Igan. 2009. Faktor-Faktor yang memengaruhi Praktik Perataan Laba. Jurnal Akuntansi dan Bisnis. Universitas Udayana. Vol.4 No.1. Januari, hal.44-55.

Cendy, Yashinta Prandyamitha. 2013. Pengaruh Cash Holding, Profitabilitas, dan Nilai Perusahaan terhadap Income Smoothing (Studi Empiris pada Perusahaan yang Terdaftar di Bursa Efek Indonesia Tahun 2009-2011). Skripsi Fakultas Ekonomika dan Bisnis. Universitas Dipenogoro.

Dewi, Made Yustiari dan I Ketut Sujana. 2014. Pengaruh Ukuran Perusahaan dan Profitabilitas pada Praktik Perataan Laba dengan Jenis Industri sebagai Variabel Pemoderasi di Bursa Efek Indonesia. Skripsi. Universitas Udayana.

Eckel, N. 1981. The Income Smoothing Hypothesis Revisited. Abacus, Juni 17(1), pp.28-40.

Keiso, D.E., Wegandt, J. J., \& Warfield, T. D. 2010. Intermadiate Accounting: Teori Agensi. JJAI, 3(2), hal.161-175.

Michelson, S.E. James, J. W. And Charles W.W. 1995. "A Market Based Analysis of Income Smoothing". Journal of Business Finance and Accounting. December. 
Nejad, Hossein Soltani., Sina Zeynali and Seyed Sadegh Alav. 2013. Investigation of Income Smoothing at The Companieslistedon The Stock Exchange By The Using Index Eckel (Case Study: Tehran Stock Exchange). Asian Journal of Management Sciences and Education, 2(2), pp.49-62.

Prabayanti, Ni Luh Putu Arik dan Grianta Wirawan Yasa. 2011. Perataan Laba (Income Smoothing) dan Analisis Faktor-Faktor yang Memengaruhinya. Jurnal Akuntansi Universitas Udayana. 6(1), hal.1-28.

Peranasari, Ida Ayu Agung Istri dan Ida Bagus Dharmadiaksa. 2014. Perilaku Income Smoothing dan Faktor-Faktor yang Memengaruhinya. E-Jurnal Akuntansi Universitas Udayana, 8 (1) hal, 69-82

Prasetya, Harris dan Raharjo, Shiddiq Nur. 2013. Pengaruh Ukuran Perusahaan, Profitabilitas, Financial Leverage, Klasifikasi KAP, dan Likuiditas terhadap Praktik Perataan Laba. Jurnal Akuntansi Diponogoro, Universitas Diponogoro,2 (4).

Pratiwi, Fernanda Lady. 2016. Analisis Mekanisme Good Corporate Governance terhadap Manajemen Laba pada Perusahaan Manufaktur yang Terdaftar di Bursa Efek Indonesia. Journal Riset Mahasiswa Akuntansi. Fakultas Ekonomi Universitas Kunjuruhan, Malang

Prayudi, Dimas dan Rochmawati Daud. 2013. Pengaruh Profitabilitas, Risiko Keuangan, Nilai Perusahaan, dan Struktur Kepemilikan terhadap Praktik Perataan Laba (Income Smoothing) pada Perusahaan Manufaktur yang terdaftar di Bursa Efek Indonesia 2008-2011. Jemasi, 9(2).

Puspareni, Putu Nita, 2015. Pertumbuhan Perusahaan Memoderasi Pengaruh Ukuran Perusahaan dan Profitabilitas Pada Praktik Perataan Laba. Skripsi. Fakultas Ekonomi dan Bisnis Universitas Udayana. Denpasar.

Scott, W. R, 2006. Financial Accounting Theory. Fourth Toronto: Pentice Hall International Inc.

Surya Dewi, Ni Made Sintya dan Latrini, Made Yenni. 2016. Cash Holding, Profitabilitas Dan Reputasi Auditor Pada Perataan Laba. Jurnal Akuntansi Udayana, 15 (3), hal. 2378-2408.

Utomo, Semcesen Budiman dan Baldric Siregar. 2008. Pengaruh Ukuran Perusahaan, Profitabilitas, dan Kontrol Kepemilikan Terhadap Perataan Laba pada Perusahaan Manufaktur yang Terdaftar di Bursa Efek Indonesia. Jurnal Akuntansi \& Manajemen, 19 (2), hal.113-125.

Yosika, Tri Santoso. 2012. Analisis Pengaruh NPM, ROA, Company Size, Financial Leverage dan DER Terhadap Praktik Perataan Laba Pada 
Ni Putu Nanda Yunika dan I Ketut Yadnyana. Pengaruh...

Perusahaan Property dan Real Estate yang Terdaftar di Bursa Efek Indonesia. E-journal Ekonomi Universitas Gunadarma. 